\title{
Informality and Protection from Health Shocks: \\ Lessons from Yemen
}

\section{Yoonyoung Cho*}

\section{The World Bank}

December 2010

\begin{abstract}
The informal sector is generally believed to be vulnerable to various risks including health shocks due to limited access to social insurance. This paper examines the relationship between informality and protection from health risks in Yemen. The formal sector includes the pension covered wage employed and largely overlaps with public employment in Yemen, while the informal sector includes the wage employed without social insurance and the self employed. Health (and nutrition), access to health service for women and children, and household health expenditures are investigated separately for urban and rural areas. The results indicate that, even after accounting for socio-economic status, water supply and quality conditions, risky behavior patterns, and unobserved heterogeneity, the formal sector is in general slightly better protected than their informal counterparts. However, there exists large heterogeneity across employment types and locality of residence (urban and rural areas).
\end{abstract}

JEL Codes: J2, I1

Key words: Informality, health insurance, health outcomes, access to health service, health spending

\footnotetext{
* Social Protection and Labor Team, World Bank, Washington DC. Email: ycho1@worldbank.org. The findings, interpretations, and conclusions expressed here are personal and should not be attributed to the World Bank, its management, its Executive Board of Directors, or any of its member countries. This paper was prepared for informality study in HD of MENA (Middle East and North Africa) region. Thanks go to Roberta Gatti and Joana Silva, for their support and insights, David Newhouse, David Robalino, Rita Almeida, and other workshop participants in 2009 at the World Bank for additional suggestions, and Afrah Ahmadi for valuable insights in understanding Yemeni insurance system. All errors are mine.
} 


\section{Introduction}

Informal sector workers are generally believed to be less protected from various risks than formal sector counterparts for various reasons. ${ }^{2}$ This is primarily because informal workers tend to be less educated and low skilled, often work in legally unprotected jobs, and reside in poorer households. In addition, informality also has implications on the ability to hedge risks due to limited access to social insurance, self insurance, and also self protection. Informal sector workers are often excluded from social protection measures that are linked to their work status. ${ }^{3}$ Informal sector workers, more likely to live in poverty and face liquidity constraints, have little option on the choice of inter-temporal savings and dissavings for self insurance. When informal sector workers are less educated and informed, and the opportunity costs of losing their earning potential is smaller, they may be more likely to engage in risky behavior with little self protection.

Little evidence exists, however, whether and to what extent informal sector is more vulnerable than formal sector. An increasing number of studies emphasize that the sector of work may not necessarily mean the vulnerability of workers since workers often choose to work in informal sector rather than being forced. ${ }^{4}$ This aspect focuses on voluntary selection into the informal sector: informal sector workers may voluntarily exit and choose informal jobs to accrue greater benefits by avoiding taxes and social insurance contributions. Hence, informal sector workers may compensate their lack of protection by circumventing taxes and other insurance contributions. Seemingly larger exposure to risks for some less educated, less skilled workers in the informal sector, who are more likely to live in poverty may not be necessarily due to informality. Moreover, informal sector workers may have better access to informal safety nets through family and community members they work with.

It is unclear what measures are needed to provide informal sector with adequate protection without disfavoring formal sector and creating distortive incentives. This is particularly true when social insurance programs, even for formal sector workers, do not properly function or provide adequate protection. Selfinsurance may be equally difficult regardless of the sector due to credit constraints and myopia. If family members' vulnerability to risks in the informal sector stems from limited access to social insurance, protection, or information, measures need to be taken to delink social insurance and relevant information from the work sector and expand insurance coverage and accessibility. However, if informal sector is no

\footnotetext{
${ }^{2}$ These risks include job loss (e.g., sudden layoff, bad weather for crops, or economic crisis), health shocks (e.g., accident or disease), longevity (e.g., outliving accumulated wealth) and the resulting income losses.

${ }^{3}$ This includes supplementary income provision in response to job losses (e.g., unemployment insurance), health shocks (e.g., health insurance) and consequent human capital loss (e.g., disability benefits), and old-age poverty (e.g., pension).

${ }^{4}$ See, for example, Perry et al., (2007) and Schneider and Enste (2000).
} 
more vulnerable than formal sector due to other informal safety net, the welfare gain from expanding social insurance may be small.

This paper investigates the informal households' vulnerability using Yemen's Household Budget Survey focusing on health. Health is a critical determinant of household well-being, especially in low income countries like Yemen where labor and human capital is usually the main source of income. Using a unique data set that includes rich information on labor market activities and health variables, this paper investigates whether Yeminis' health, access to care, and burden of spending systematically differ by sector, and if so, the underlying reasons for these differences. This paper contributes to a better understanding of informality and its implications on household welfare in health.

Sector is defined based on access to social insurance. ${ }^{5}$ Wage employed workers provided with pension or health insurance or both are formal, whereas workers without limited access to social insurance coverage are informal. Among the formal wage employed, those with both health and pension coverage are separately categorized with those with pension coverage only. Informal workers include the wage employed and the self employed.

The findings are as follows: in general, formal wage employed households have the best outcomes in health, access to service, and protection from catastrophic health expenditure. On the other hand, informal wage employed households are the least protected. Extra income, better information, and increased self-protection appear to play an important role in protecting formal workers even after controlling for their socio-economic characteristics. Finally, informal networks and remittances, as well as larger family size somewhat reduce the risks among self-employed households.

The paper is organized as follows. Section two provides a review of concepts and issues related to informality. Section three describes the data and institutional background regarding health protection. Section four presents a descriptive analysis of the main variables used in the study. Section five presents the empirical strategy to investigate the differences in outcomes across work status, and the analysis results. Section six summarizes and concludes the study.

\section{Informality and Health Shocks}

A large body of literature on informality often has focused on its definition, size, and determinants and consequences from enterprise' or workers' perspectives. ${ }^{6}$ Despite these efforts, little consensus exists and informality is often characterized as mixture of lax regulation, an absence of records and taxation, and a

\footnotetext{
${ }^{5}$ This is in line with many other studies that defined informality based on protection through social security. See Portes, Blitzner, and Curtis (1986), Marcoullier et al. (1997), and Saavedra and Chong (1999).

${ }^{6}$ See Hart (1973) for a seminal work on informality; Frey, Weck, and Pommerehne (1982), Cassel and Cichy (1986), and Schneider and Enste (2000) for informality as a hidden economic activities; Tanzi, (1999), Thomas (1999), and Giles (1999) for discussion on the size of informal sector.
} 
large presence of unprotected, low-skilled workers. Studies often take an either side of enterprises or workers to examine the implications of informality. From the enterprises' perspective, studies highlight various incentives to enter the informal sector, including excessive tax rates, a high degree of regulation, and social insurance contribution (De Soto, 1989; Friedman et al. 2000; Maloney, 2004). More relevant for this paper, studies focusing on the workers' perspective examine the characteristics of informal sector workers, and emphasize their productivity and protection.

In general, informal workers, who are less educated, less skilled, and from low income families, often have no choice but to work in informal sector and tend to have low earnings. However, informal workers are not monolithic, but in fact, a heterogeneous group exhibiting a wide range of variation. Several studies challenge the notion that informal employment only entails low quality jobs where workers with no other employment options are forced to participate in. Marcoullier et al. (1997), for example, examine the wage premium of the formal over informal sector in Mexico, El Salvador, and Peru. Informal workers are defined based on the enterprise size or social security coverage. They found positive wage premium for work in the formal sector in El Salvador and Peru, but not in Mexico.

Informal sector likely has limited access to insurance and is less protected from poverty induced by shocks. Most social insurances such as pension, unemployment benefits, and health insurance are only provided to formal sector employees. Not having access to social insurance reduces risk pooling and savings options to insure against risks (Gertler and Gruber, 2002). However, the causal relationship between informal sector employment and vulnerability is unclear. Extra income accumulated from nonpayment of taxes, and the use of informal safety nets present in the informal economy may reduce vulnerability of informal sector. ${ }^{7}$ Some studies have found that the informal sector serves as an informal safety net for the poor (Ferman, Henry and Hoyman, 1987). The informal sector also provides employment opportunities for workers in transit and marginalized workers such as women (Carneiro et al. 2008). Gulyani and Talukdar (2010) found that informal activities, including micro enterprises, actually helped alleviate poverty.

Health insurance as well as pension is one of the most frequently discussed social insurance that needs to expand its coverage to informal sector. The importance of health insurance comes from the fact that human capital is the only available capital for many people in developing countries, loss of health imposes huge costs, and that health risks are least predictable and quite sizeable shocks. Health insurance fails to cover informal sector and even among formal sector the coverage can be very low due to low enrollment (Wagstaff, 2009). Findings that the poor are less well-insured against income risks suggest that informal households are also less-well insured as they tend to be poorer (Jalan and Ravallion, 1996). Baeza

\footnotetext{
${ }^{7}$ See Richard J. Cebula (1997), for the impact of the income tax rates on labor supply across formal and informal sector.
} 
and Packard (2006) notes that large scale risk pooling can greatly mitigate the risk of income loss due to health shocks. However little is known about the extent to which health insurance reduces vulnerability to the health shocks.

\section{Data and Institutional Background}

\section{$\underline{\text { Data }}$}

This study uses a nationally representative Yemen Household Budget Survey (HBS) conducted in 2006. In examining health risks by work status, the data should contain information on both health and labor market outcomes. The wealth of information on health as well as individual demographic and socio-economic characteristics, labor market indicators, and household living conditions, income, and expenditure enable to analyze the health implications of informality. ${ }^{8}$

The Yemen HBS collected information on 13,121 households and 98,845 individuals. Among 56,600 adults aged fifteen or above, 20,888 individuals are working as either wage employed or selfemployed. ${ }^{9}$ Among wage and salaried workers, some receive employer provided pension coverage while others do not. In line with many studies defining informality based on access to social security, formal workers are workers with pension, a subset of wage and salaried workers. Informal workers are wage and salaried workers without pension and self employed workers. With respect to households, in order to group them exclusively, households are defined to be formal if at least one member of the household works in wage employment receiving pension. If all working members of a household are self employed, it is defined as a self-employed household.

The data contains nutrition and health information for children under six, health and service use information for adults, and health spending for households. Children's nutrition measures, such as underweight and stunting, are constructed using objective measures of weight and height. Health measures include self-reported disability and chronic diseases, illness, and accidents. Health care service information includes each child's immunization, assisted child delivery, and regular health checkups with health professionals. $^{10}$

\section{$\underline{\text { Health and health care in Yemen }}$}

\footnotetext{
${ }^{8}$ A Labor Force Survey includes detailed information on labor market indicators including employment status and sector, job search efforts, and earnings, but often lacks information on health. On the other hand, Demographic Health Survey has detailed information on health, but misses labor market indicators.

${ }^{9}$ Among those not working, it is unclear whether they are still in the job search process. Thus, defining an economically active population using a standard definition is not possible here.

${ }^{10}$ World Bank (2007) noted that the questionnaire of HBS 2005 did not clearly distinguish if the question meant to ask about delivery by a doctor, midwife or a medically trained professional.
} 
The most serious health problem faced by Yemenis is women and children's health, where the achievement of Millennium Development Goals (MDGs) proves challenging. Child malnutrition is strikingly prevalent in Yemen where more than half of children under five suffer from malnutrition. ${ }^{11}$ This is among the world's highest child malnutrition rate along with Iraq and Sudan. Progress towards reducing the child malnutrition rate by half has been slow. The maternal mortality rate, 365 deaths per 100,000 lives, is the highest among the Middle East and North Africa (MENA) region countries. ${ }^{12}$

While health indicators in Yemen pose a serious problem, access to health services are low, and services for major treatments are prohibitively expensive. The government, Ministry of Public Health and Population (MOPHP), is the main health service provider in Yemen. They operate a three-tier network of primary, secondary, and tertiary level facilities through governorate and district health offices. One of the major challenges of the Yemeni health system is low coverage among the population. Furthermore, large discrepancies exist in levels of coverage between urban and rural areas (Fairbank, 2009). Due to the limited delivery of health services, particularly in rural areas where approximately three-fourths of the population are concentrated, Yeminis face challenges in achieving maternal and child health related Millennium Development Goals (MDGs). ${ }^{13}$

In addition to the lack of health service delivery, an underinstitutionalized financial payment system presents another barrier to health care in Yemen. Since there is no existing health insurance scheme in Yemen, health expenditures mostly come from out-of-pocket payment. While public health spending from MOPHP provided service comprises $1.8 \%$ of GDP, private out-of-pocket expenditure is about two times larger at 3.4\% of GDP (Fairbank, 2009). Only a slight proportion of government workers receive reimbursement for utilized health services. Even out-of-pocket expenditures, however, are a concern to those who have access to health services. Since a large proportion of the population has limited access to service, the out-of-pocket expenditure occurs only to the well-off or the severely ill. Households with disabled or chronically ill members are exposed to large losses in income, but there is no risk pooling instrument available in Yemen.

\section{Descriptive Analysis}

Formal sector workers and their households may have better protection from health shocks for multiple reasons: (i) they might have higher education and more work experience due to job stability and are likely to have higher earnings; (ii) they might have better access to health insurance; (iii) they might have better information on health care service; (iv) they might be more risk averse and careful about their health; and

\footnotetext{
${ }^{11}$ See UNICEF (2006)

${ }^{12}$ See World Bank (2009)

${ }^{13}$ For example, MDGs 4 and 5 are not likely to be met in Yemen. MDG 4: Reducing child mortality and morbidity and MDG 5: Improving maternal health.
} 
(v) those with better health may have a better chance to work in the formal sector. Although this paper does not exhaustively address all the reasons mentioned above, individual characteristics (e.g., age, education, and work experience), household characteristics (e.g., income quintile, number of adults and children, non-labor income and transfer), health insurance availability, and risky behavior patterns (e.g., smoking or qat chewing) are considered as long as the data permits. Keeping this in mind, the characteristics of formal and informal workers and households by employment status are presented below.

\section{Characteristics of Workers and Jobs in Each Sector}

Recall that among all employed workers, those who are wage employed and provided with pension are categorized as formal workers; other wage workers and the self-employed are categorized as informal workers (See Figure 1). Among formal workers, a small fraction reported they received employer provided health insurance. Households with anyone working for pension providing employers are referred to as formal households. Among informal households, if all employed workers in the household are selfemployed, they are categorized as self-employed households.

Formal workers largely overlap with public sector workers. The proportion of public workers among formal workers is $97 \%$, and the proportion of formal workers among public workers is $89 \%$. About $25 \%$ of working individuals are formal. Among formal workers, about $28 \%$ are covered by health insurance. Informal wage employees work mostly in the private sector. They count for roughly $38 \%$ of the employed. The rest, $37 \%$ of the employed, is self-employed (Table 1). ${ }^{14}$ The proportion of formal workers is higher in urban areas, while the proportion of informal wage workers and self-employed workers are higher in rural areas.

\footnotetext{
${ }^{14}$ Throughout the paper, outcomes are presented by household or worker type: formal workers with health insurance (formal with HI), formal workers with pension coverage only (formal with PN), informal wage workers without any social insurance (informal wage), and self employed.
} 
Figure 1. Category of workers:

by employment status and social insurance coverage

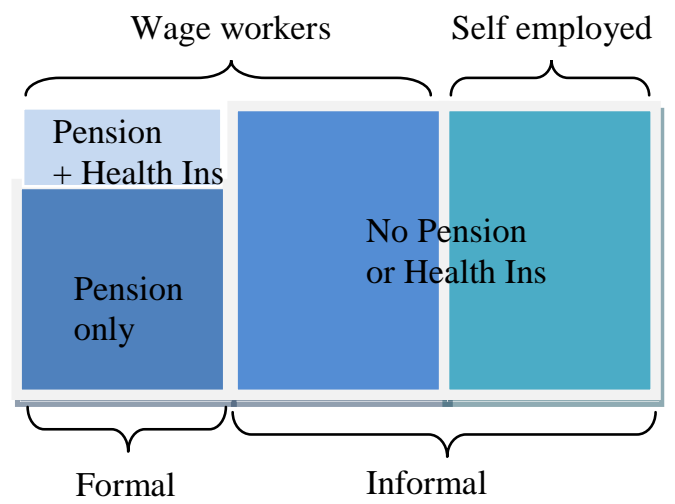

There are clear differences in demographic characteristics across different types of workers. Several of these differences are more striking in urban than rural areas. Formal workers are significantly more educated with more than half having received tertiary education. On the other hand, self-employed workers are the least educated group; about half $(51 \%)$ have no schooling. Educational attainment is a lot higher in urban areas, and the urban/rural educational gap is particularly larger for informal wage workers. Self-employed workers tend to have larger families with more children, live in rural areas, and work in agriculture. One interesting observation here is that formal workers (especially those without health insurance) are more likely to have multiple jobs, particularly in rural areas. The formal sector, which overlaps with the public sector, consists of mostly male workers. Female employment is extremely low, though urban women have slightly higher chances of work, especially in the formal sector. Informal wage employed workers are slightly younger than formal or self-employed workers.

Job characteristics, including benefits and years of experience, are provided among wage employed (formal and informal) but not self-employed workers. Monthly earnings are taken from a worker's main occupation, regardless of the number of jobs held. Formal workers with health insurance have the highest earnings, followed by informal wage workers, and then formal wage workers without health insurance. Among wage workers, formal workers tend to be older and more experienced in the current job, are paid monthly, and receive employer provided benefits such as paid leave and health insurance. Despite higher education and longer job experience, the total monthly earnings for public sector workers are less than those of private sector workers. This may be attributed to shorter working hours for public sector workers. 


\section{Household Income}

In addition to labor earnings from a worker's primary occupation, households often receive a relatively large amount of additional income, which may act as a source of informal safety net (Table 2). The amount of extra income varies greatly across these three groups, although the proportion of workers who have positive extra income is similar. Formal workers are more likely to have positive pension income in the household, implying that public employment is inter-generationally correlated. Public assistance, which supposedly targets low income households, is somewhat evenly distributed, although the receipt is more common among informal wage workers. Private transfers from relatives and friends, and dissaving from assets is most common among the self-employed, which suggests their dependence on informal safety nets. The total extra income is similar for formal households and the self-employed, but significantly lower for informal wage employed households. These patterns consistently appear when examined separately by region.

Earnings and income are strikingly different between urban and rural workers. Although rural households more frequently receive private transfers, the average amount is larger for urban households. Sales and interest, and other types of income occur more frequently and in larger amounts for urban households. When income quintiles are calculated based on household nonfood consumption, formal households are more likely to be found in higher income quintile groups. In urban areas, informal wage workers are found in higher income quintiles than the self-employed. Rural workers are more likely to hold multiple jobs. Despite large urban/rural income discrepancies, public transfers are allocated similarly, which again raises concerns about targeting of the public safety net programs.

\section{Health Outcomes, Access, and Expenditure}

Health outcomes include indicators of severe illness (disability or chronic diseases), non-chronic disease and accident for adults, and indicators of stunting, underweight, and severe illness for children under six (Table 3). Access to health service is measured with indicators of assisted delivery, medical help when sick, and child immunization. Financial burden due to health spending is measured as per capita health expenditure in the household. Finally, indicators of catastrophic expenditure are based on the proportion of health expenditure out of nonfood consumption.

Child outcomes reconfirm the serious health situation in Yemen. A significant proportion of children are severely stunted, and the incidence of underweight and illness is also high. Nutrition outcomes are slightly better for children in formal sector households and the difference is clearer for urban children. Nutrition outcomes do not necessarily go with the health outcomes: Nutrition status is better among urban children, while health outcomes are better for rural children. The outcomes of formal households with 
health insurance are no better or often worse than those of formal households without health insurance. About $14 \%$ of women are disabled or chronically ill, and almost $23 \%$ are experiencing illness if accidents and other non-chronic illness are included. Urban women are more likely to be ill than their rural counterpart, and, in urban areas, formal households seem to have poorer health than informal households.

Health care service is best accessible by formal households, and the self-employed have similar or slightly better access than informal wage employed workers. Access to care widely varies across region, particularly in assisted delivery. Per capita expenditure on health, probably reflecting household income level, is highest among formal and lowest among informal wage employed workers. However, based on the incidence of catastrophic expenditure, formal households appear to be better protected from health shocks compared to informal households.

\section{What Determines Sector Assignment?}

\subsection{Multinomial logit}

A worker is observed to be in one of the four mutually exclusive employment types: wage employment with pension and health insurance $(\mathrm{H})$, wage employment with pension only $(\mathrm{P})$, wage employment without pension or health insurance $(\mathrm{N})$, and self employment $(\mathrm{S})$. Let $Y_{i j}$ denote the unobserved propensity for an individual $i$ to hold $j$ type of employment, which is determined by worker and market characteristics. The individual is assigned to be in the type which gives the highest value for the unobserved propensity. This means that

$$
T_{i}=\left\{\begin{array}{l}
H, \text { if } Y_{i H}=\max \left(Y_{i H}, Y_{i P}, Y_{i N}, Y_{i S}\right) \\
P, \text { if } Y_{i P}=\max \left(Y_{i H}, Y_{i P}, Y_{i N}, Y_{i S}\right) \\
N, \text { if } Y_{i N}=\max \left(Y_{i H}, Y_{i P}, Y_{i N}, Y_{i S}\right) \\
S, \text { if } Y_{i S}=\max \left(Y_{i H}, Y_{i P}, Y_{i N}, Y_{i S}\right)
\end{array}\right.
$$

where $T_{i}$ is an actual type of employment that $i$ was assigned.

Let $Y_{i j}$ be specified as a linear function of observable characteristics $\left(X_{i}\right)$ and unobservable random errors following a standard normal distribution conditional on $X_{i}$. Then, $Y_{i j}=\Pi_{j}{ }^{\prime} X_{i}+\epsilon_{i j}$ and the standard multinomial logit yields

$$
\operatorname{Pr}(T=j)=\frac{\exp \left(\Pi_{j^{\prime}} X\right)}{\sum_{j} \exp \left(\Pi_{j^{\prime}} X\right)} \text { with } j=H, P, N, \text { and } S .
$$

Using the informal wage employment $(\mathrm{N})$ as a base category, the multinomial logit was estimated. Worker's characteristics including age, education, and marital status, and governorates dummy capturing local characteristics including labor market conditions are added. Subsamples of locality of residence and employment status are also considered. 
Table 4 shows the results from multinomial logit estimation. ${ }^{15}$ As the informal wage employment is the base category, the estimates read the relative propensity of working in other types of employment rather than informal wage employment. Age, marriage, and education are positively associated with formal employment. That is, older and better educated workers are significantly more likely to work in formal sector than informal. The effects of some variables are heterogeneous across urban and rural areas. In urban areas, secondary education and above is negatively related to self employment rather than informal wage employment, and being a household head and having a pensioner in the household are significantly related to formal sector working. Also being born at current locality of residence is negatively related to informal wage employment, implying that those who lack local network may tend to work in informal wage employed jobs. In rural areas, however, those with secondary and above education and social network by being born in the same locality tend to work in self employment rather than informal wage employment.

The coefficients of each estimation, taken together and examined with the likelihood ratio test, shows significant differences from zero for both urban and rural areas. This means an overall non random sector assignment. In order to examine if sector assignment even between formal with health and pension coverage $(\mathrm{H})$ and pension only $(\mathrm{P})$ is statistically different across observable characteristics, the null hypothesis that difference in the coefficients of column (1) and (2) is zero is tested. For urban areas, the Chi Square value is 15.8 and the null hypothesis is rejected only at $10 \%$ level whereas, in rural areas, the Chi Square value is 26.5 and the null hypothesis is rejected at $1 \%$ level. This implies that assignment between each type of employment including $\mathrm{H}$ and $\mathrm{P}$ is also nonrandom, although workers in $\mathrm{H}$ and $\mathrm{P}$ in urban areas are quite similar.

\subsection{Selectivity Corrected Outcomes}

Let the outcomes $\left(O_{i j}\right)$ such as wage and health be determined jointly with sector assignment. Then $O_{i j}=\beta_{\mathrm{j}}^{\prime} \mathrm{Z}_{\mathrm{i}}+\varepsilon_{\mathrm{ij}}$, where $j=H, P, N, S$. Taking conditional expectation over all individuals on sector assignment yields $E\left(O_{j} \mid T=j\right)=\beta_{\mathrm{j}}^{\prime} \mathrm{Z}+E\left(\varepsilon_{\mathrm{j}} \mid \mathrm{T}=j\right)$. Selectivity into each type of employment implies that $\mathrm{E}\left(\varepsilon_{\mathrm{j}} \mid T=j\right) \neq 0$ and the Ordinary Least Squares (OLS) estimate is not consistent. Following Lee (1983) and the Handbook of Econometrics (1984), the selectivity corrected model is estimated as

\footnotetext{
${ }^{15}$ The multinomial logit model assumes the Independence of Irrelevant Alternatives (IIA) property of each error terms $\left(\epsilon_{i j}\right)$. This implies that each choice of employment type independently takes place. If workers are first assigned to the formal and informal sector, and then subsequently assigned either to $\mathrm{H}$ or $\mathrm{P}$, and $\mathrm{N}$ or $\mathrm{S}$, this assumption no longer holds. Alternatively, if workers are first assigned to wage and self employment and then, within wage employment, assigned between $\mathrm{H}, \mathrm{P}$, or $\mathrm{N}$, the IIA assumption is violated. HAUSMAN TEST
} 


$$
O_{j}=\beta_{\mathrm{j}}^{\prime} \mathrm{Z}+\gamma_{\mathrm{j}} \lambda_{\mathrm{j}}+\mathrm{v}_{\mathrm{j}}, \text { where } \lambda_{\mathrm{j}}=\frac{\phi\left(\Phi^{-1}(\operatorname{Pr}(\mathrm{T}=\mathrm{j}))\right)}{\operatorname{Pr}(\mathrm{T}=\mathrm{j})}{ }^{16}
$$

In this case, the standard errors should be corrected as well because the selectivity is unobserved. Using a Bootstrapping method with generating $\lambda_{\mathrm{j}}$ for 100 times, the corrected standard errors are obtained.

\section{Do health, access to care, and expenditure differ by employment type?}

The focus is whether health, access to care, and expenditure differ by employment types, and how much is explained by observable differences and selectivity. That is to answer the following questions: Is there a difference in outcomes across employment types?; Is it due to selectivity?; When selectivity is accounted, is there still a difference in outcomes by employment types? In order to examine the presence of selectivity, I report the statistical significance of selection correction term $\left(\lambda_{j}\right)$. I then turn to the comparison of outcomes between employment types. Difference in predicted values of outcome, for example between $\mathrm{P}$ and $\mathrm{N}$, can be explained by intrinsic difference across employment type, observable differences among workers, and selectivity. From equation (3), taking differences of mean values of outcomes for $\mathrm{P}$ and $\mathrm{N}$ yields:

$$
\overline{O_{P}}-\overline{O_{N}}=\left(\widehat{\beta}_{\mathrm{P}}-\widehat{\beta}_{\mathrm{N}}\right)^{\prime} \overline{\mathrm{Z}}_{\mathrm{p}}+\widehat{\beta}_{\mathrm{N}}{ }^{\prime}\left(\overline{\mathrm{Z}_{\mathrm{p}}}-\overline{\mathrm{Z}_{\mathrm{N}}}\right)+\left(\hat{\gamma}_{\mathrm{P}} \overline{\lambda_{\mathrm{P}}}-\hat{\gamma}_{\mathrm{N}} \overline{\lambda_{\mathrm{N}}}\right) .
$$

The second and third part is due to differences in observable and unobservable characteristics, respectively. The first part reflects differential effects of the common characteristics. For example, mothers' education may have stronger impacts on child's health in informal wage employed families $(\mathrm{N})$ than in formal wage employed $(\mathrm{P})$.

I present estimation results including the selectivity term and test whether the differences across employment types are due to employment types. I repeat this exercise for children, women, and household outcomes. When outcomes of interest are children, mother's characteristics such as their age, education, and some behavioral patterns including breastfeeding and smoking and qat chewing are added to $Z$ as well as household conditions, while selection into each employment type is determined by father's characteristics. ${ }^{17}$ Likewise, when women's outcomes are estimated, their own characteristics are used in $Z$ whereas selection is determined by husbands' characteristics. Finally, households' outcomes are estimated based on household head's characteristics.

\footnotetext{
${ }^{16}$ Note that $\phi$ and $\Phi$ denote probability density and cumulative distribution function of standard normal distribution.

${ }^{17}$ Although mothers' breastfeeding is expected to affect child's outcomes, the reverse is also possible: child's nutritional condition may induce mothers' behavioral change. In order to avoid simultaneous decision and endogeneity, the indicator of breastfeeding is one when the mother had breastfed other siblings in the household.
} 


\subsection{Children's nutrition and health}

Selectivity corrected estimation of severe stunting in urban and rural areas show several consistent patterns (Table 6-7). Mothers' age and education, if not monotonically, reduce the likelihood of stunting. The number of children under six is associated with stunting, suggesting resource (food and nutrients) constraints as main factor in child's malnutrition. Income quintiles are not significant determinants of stunting, whereas water supply and quality have significant effects. Having enough water supply, especially inside a house without having to fetch, and treating water can significantly reduce stunting. The coefficients of selectivity are statistically significant for some employment types, meaning that unobserved characteristics associated with employment selection affect child's nutrition.

There is heterogeneity in results across regions and employment types. In rural areas, mothers' behavior has significant effects on child's nutrition as expected: breastfeeding has positive effects, whereas their smoking and qat chewing adversely affects child's nutrition. However, in urban areas, mothers' behavioral variables are not such significant determinants of severe stunting. The magnitude of water treating effects on severe stunting is larger and varies more widely in rural areas than urban: variation ranges from 10 to 30 percentage points by employment types in rural areas, but from 5 to 11 percentage points in urban areas. In urban areas, unobservable selectivity has positive effects in self employed households, while in rural areas it has negative effects in informal wage employment.

Similar results are found for child's underweight, another indicator of nutrition, and child's health captured by the indicator of illness. The magnitude of impacts is sometimes different for health than nutrition measures. ${ }^{18}$ The effects of water supply and quality are strongly associated with child's health as well as nutrition. Mother's smoking and qat chewing is more closely related with child's health than nutrition. Mothers' smoking and qat chewing increase the probability of ill health by 6 to 17 percentage points. Meanwhile, mother's breastfeeding is very closely with child's nutrition, but has nonsignificant effect on illness.

\subsection{Women's health}

Women's illness is an indicator of chronic disease, non-chronic and minor illness, and accidents, and the estimation results are presented in Table 6 and 7. For both regions, the likelihood of illness increases with women's age, but decreases with education. Women's smoking and qat chewing has strong and significant effect on health. Water supply and quality condition is also an important determinant of women's health as it was for child's health. Number of children under six is negatively associated with women's illness. Mothers with young children are probably more health conscious and careful not to fall ill. Alternatively,

\footnotetext{
${ }^{18}$ The results for severe underweight and illness were not presented here, as they are similar to those of severe stunting.
} 
healthier women may have higher parity as well as low infant fatality. Selectivity is statistically significant for some employment types.

Household income has little to do with women's health indicator in rural areas. In urban areas, however, the highest income quintile is strongly associated with women's illness. This is a puzzling result and calls for caution in interpreting. Positive relationship between income and illness can be explained if higher income women have better access to medical service and more likely to learn about their illness. This suggests the limitation of self reported health measures and the importance of objective measures such as the ones based on BMI or more objective self reported measures. ${ }^{19}$

\subsection{Access to Care and Health Expenditure}

Among the three variables (indicators of child immunization, assisted delivery, and medical help when sick) capturing access to health care, I present estimation results for medical help in case of illness. Likewise, among a few measures capturing household health expenditure, I present the results for the proportion of health expenditure among total consumption. For these estimations, I added an indicator of presence of household member with disability. Panels A and B in Table 8 and 9, respectively, show the results for urban and rural areas. ${ }^{20}$

Older women and those with young children have less access to health service, especially in rural areas, which may reflect their limited mobility to utilize health service. The effects of education are not monotonous. In urban areas, women with higher education generally have better access, whereas those with primary education are often worse off than their no education counterparts in rural areas.

As noted earlier, health expenditure occurs mainly to those well off households that can afford to pay for health service and those with severe illness. The proportion of health expenditure among household consumption decreases with education of the head and household income level. Having a household member with disability significantly increases household health expenditure.

\subsection{Health, access to care, and health expenditure across employment types}

Having examined each outcome of interest with selection corrected estimation, I now turn to differences in outcomes across employment types. Separately for urban and rural areas, I examine whether the difference in outcomes are statistically meaningful. These differences are decomposed into three parts as specified in equation (5). In all cases, informal wage employed $(\mathrm{N})$ is used for base category.

\footnotetext{
${ }^{19}$ The limitations of subjective self reported health measures in assessing physical capacity are widely recognized. For review of health measures, see Currie and Madrain (1999).

${ }^{20}$ Results that are not presented here due to the limited space can be obtained from author upon request.
} 
Findings show that child's severe stunting is significantly more prevalent among informal sector households in both urban and rural areas. In urban areas, the all the paired differences are statistically significant, and the likelihood of severe stunting is highest among self employed and lowest among pension-only formal households. In rural areas, there is little difference within informal sector between wage employed and self employed. Formal sector households are overall better off than informal ones, despite high chances of stunting among health insured households because of better outcomes among pension only formal households. The gap between the worst and best group is almost 7 percentage points (3.4-(-3.5)pp) in urban and 5.5 percentage points (1.1-(-4.4)pp) in rural areas. In most cases except rural (H-N) difference, differences due to observable characteristics have the same sign with the overall differences, implying that the predicted outcome difference is consistent with their observable differences. However, even counting for observable differences, there exists an outcome differential for observationally identical households.

Women's illness shows similar patterns in that formal households fare better than informal counterparts, and this is clearer in rural areas. However, in rural areas, the proportion explained by observable differences is relatively small and there is wide variation in differences due to intrinsic features of employment and unobservable characteristics.

In terms of access to service, health insured households in urban areas significantly have better access to medical help than other households by about 13.7 percentage points. In rural areas, the paired differences across households are muted. I tested the differential access to service using other variables such as assisted delivery. It also shows that formal households especially the health insured ones in urban areas tend more to utilize medical service in child delivery.

Finally, the proportion of health spending out of household expenditure is lowest for households with pension only and highest for health insured households. Households with health insurance especially in rural areas have significantly higher health spending compared to their income. This suggests that health insurance plays a role in increasing households' access to medical service especially in urban areas, but does little in reducing expenses.

\section{Does Informal Safety Net Vary with Employment type?}

\subsection{Nonlabor Transfers and borrowing}

Nonlabor transfers including public transfers from government and public programs, private transfer from NGOs and religious groups and other types of income would serve as an informal safety net in the case of external shock. As shown earlier, a disabled household member is a distress factor in health expenditure especially for informal sector households (See Table 9). I examine to what extent extra nonlabor income 
reduces the financial burden associated with household member with disability and how it varies with household type.

Inter-temporal resource allocation - savings and loans- is a commonly used risk coping mechanism. Unfortunately, information on savings is not available. However, information on loans is available. Households often resort to informal sources such as friends and relatives (not residing together) rather than banks or money lenders to borrow money. ${ }^{21}$ The likelihood of borrowing increases with the presence of a disabled household member. The question is again the extent to which the health shock increases the likelihood of borrowing, and how it varies with household types.

The coefficients of the indicator of disabled household member in the regressions on indicators of transfer and borrowing are presented in Table 10. In urban areas, disabled household member significantly increases the likelihood of transfer incomes among informal households by 6 percentage points. Borrowing also increases with the residence of disabled household member by 6 to 13 percentage points. The likelihood of borrowing in presence of disabled household member is the largest for the self employed. In rural areas, the likelihood of receiving transfer income due to disability is highest among formal households without health insurance. The incidence of borrowing increases with disabled household member by 9 to 11 percentage points, and is slightly higher for informal households.

\section{Conclusion}

Like other developing countries and transition economies, the informal sector provides many Yemenis work opportunities and consists of a large proportion of the labor market. A substantial proportion of the wage employed and almost of all self employed workers, not covered by any social insurance programs, are almost 70 percent of workers. About 52 percent of households do not have anyone working in formal sector. These workers and their households are believed to be more vulnerable to various risks due to the limited access to social insurance. Health risks are among the most common risks faced by many individuals and households, and particularly so in Yemen where national health outcomes are known to lag behind.

This paper investigated the relationship between informality and health risks, noting that there is little empirical evidence of differential vulnerability to risks across employment types. I first outlined the main characteristics of workers by employment and coverage status. Findings show that formal wage workers, mostly public sector workers, tend to be substantially more educated, older, and more experienced. They generally fall on a higher income quintile, although their earnings are no larger than those of informal wage workers. They are less likely to work in the agriculture sector, and more likely to

\footnotetext{
${ }^{21}$ Sources of the outstanding loan include relatives (30\%), friends and neighbors (35\%), and traders (29\%).
} 
receive regular payment and benefits. Formal wage employed households are more likely to have current pensioners, implying a high intergenerational correlation of public sector jobs. Among informal workers, self-employed workers are less educated than wage employed workers, but their income level is not lower, partly due to private transfer and sales income. A large discrepancy in worker and household characteristics was found between urban and rural areas.

Health, access to service, and health expenditure in the household widely vary along the employment types. Selection corrected model was estimated in order to account for unobservable heterogeneity that affects sector assignment in determining health related outcomes, as well as observed characteristics. In most cases, unobserved heterogeneity significantly affects outcomes of interest, implying that omitting this would bias the estimates. Outcomes are quite different across different employment types of household heads (child's father and women's husband), even when considering for all these observable differences in characteristics and locality of residence. Differences between formal and informal households with observationally identical characteristics still persisted.

Outcomes are, in many cases, better for formal than informal households and these gaps persist even for observationally equivalent workers. The results suggest that health insurance provides little explanation on better outcomes among formal workers. It may even increase the households' health expenditure due to increased access to service, especially in rural areas. In the presence of disabled workers, informal households face a significant increase in health spending. This is likely to be financed by transfer income and borrowing, which serve as informal safety net.

Given a wide heterogeneity between formal and informal and even within those sectors, in their exposure to health risks, health outcomes, coping mechanism, and spending, and also their poverty, more research is needed to find a suitable insurance scheme that combines risk pooling and saving for the poor. In the mean time, rather than providing protection through work, a general approach would be more appropriate to address widespread health and malnutrition problems. For example, child stunting and related diseases are preventable by early intervention including micronutrient fortification and education on breastfeeding practice (Cho and Rassas, 2009). As shown in the results, water supply and quality condition as well as mother's behavior are very important factors in health, and should be promoted regardless of employment status or availability of social insurance. 


\section{References}

Adam, Markus C. and Victor Ginsburgh. 1985. "The Effects of Irregular Markets on Macro-economic Policy: Some Estimates for Belgium," European Economic Review, 29:1, pp. 15-33.

Assaad, Ragui. 1997. "The Effects of Public Sector Hiring and Compensation Policies on the Egyptian Labor Market," World Bank Economic Review, 11(1), 85-115.

Baeza, Cristian and Truman Packard. 2006. Beyond Survival: Protecting Households from Health Shocks in Latin America, World Bank. Washington DC.

Bagachwa, M. S. D. and A. Naho. 1995. "Estimating the Second Economy in Tanzania," World Development, 23:8, pp. 1387-99.

Behrman, J. R. 1997. "Intrahousehold distribution and the family" in Handbook of population and family economics, ed. M. R. Rosenzweig and O. Stark. Amsterdam: North-Holland Publishing Company.

Canagarajah, Sudharshan and S. V. Sethuraman. 2001. "Social Protection and the Informal Sector in Developing Countries: Challenges and Opportunities," Social Protection Discussion Paper Series, 0130. World Bank, Washington DC.

Carneiro, F., A., Henley, and R. Arabsheibani, 2009. "On Defining and Measuring the Informal Sector: Evidence from Brazil,” World Development 37 (5): 992-1003.

Cassel, D. and U. Cichy, 1986. "Explaining the Growing Shadow Economy in East and West: A Comparative Systems Approach," Comparative Economic Studies. 28: 20-41.

Castells, M. and A. Portes, 1989. World underneath: The Origin, Dynamics, and Efforts of the Informal Economy. In A. Portes, M. Castells, and L. Benton (Eds.), The Informal Economy Studies in Advanced and Less Developed Countries (pp. 11-37) Baltimore: Johns Hopkins Press.

Chiappori, 1992. "Collective labor supply and welfare.” Journal of Political Economy 100 (3): 437-467.

Chiappori, 1997. "Introducing Household Production in Collective Models of Labor Supply." Journal of Political Economy 105(1): 191- 209.

Cho, Y. and B. Rassas. 2009. "Unfinished Agenda: Child Malnutrition in MENA" mimeo, World Bank, Washington DC.

Cohen, B., \& House, W. J. (1996). Labor Market Choices, Earnings and Informal networks in Khartoum, Sudan. Economic Development and Cultural Change, 44(3), 589-618. 
Cunningham, W. V., \& Maloney, W. F. (2001). Heterogeneity among Mexico's microenterprises: An application of factor and cluster analysis. Economic Development and Cultural Change, 50(1), $131-156$.

Currie, J. and B.C.Madrian, 1999, "Health, Health Insurance and the Labor Market" in O. Ashenfelter and D. Card (eds.), Handbook of Labor Economics v. 3c, New York: Elsevier, 3309-3416.

De Soto, H., 1989. The Other Path, Harper and Row, New York.

Dilnot, A., and C., Morris. 1981. What Do We Know About the Black Economy in the United Kingdom? Fiscal Studies, 2, 163-79.

Ehrlich, Isaac, and Gary Becker. 1972. "Market Insurance, Self Insurance, and Self Protection.” Journal of Political Economy, Vol. 80: 623-48.

Elbadawi, Ibrahim, and Norman Loayza. 2008. "Informality, Employment, and Economic Development in the Arab World," The World Bank, Washington DC.

El Saharty, Sameh and Akiko Maeda, 2006. Egypt Health Sector Brief. Middle East and North Africa, World Bank, Washington DC.

Fairbank, Alan. 2009. Health Financing Modalities in Yemen: Possibilities for Results Based Financing and Social Health Insurance, Yemen Health Sector Review. The World Bank, Washington DC.

Feige, Edgar L. 1979. "How Big is the Irregular Economy?" Challenge, 22:1, pp. 5-13.

Frey, B., H. Weck, and W. Pommerehne, 1982. Has the Shadow Economy Grown in Germany? An Exploratory Study. Review of World Economics, 118. 499-524.

Friedman, Eric, Simon Johnson, Daniel Kaufmann, and Pablo Zoido-Lobaton. 2000. "Dodging the Grabbing Hand: The Determinants of Unofficial Activity in 69 Countries." Journal of Public Economics, 76, 459-93.

Giles, David E. A. 1999a. "Measuring the Hidden Economy: Implications for Econometric Model-ling," Economic Journal. 109:456, pp. 370-80.

Gindling, T. "Labor Market Segmentation and the Determination of Wages in the Public, Private-Formal, and Informal Sectors in San Jose, Costa Rica," Economic Development and Cultural Change 39 (April 1991): 585.

Guerrero-Serdan, Gabriela. 2009. "The Effects of the War in Iraq on Nutrition and Health: An Analysis Using Anthropometric Outcomes of Children,” MPRA Working Paper \#14056. 
Glewwe, Paul and Gillette Hall, 1998. "Are Some Groups More Vulnerable to Macroeconomic Shocks than Others? Hypothesis Tests Based on Panel Data from Peru," Journal of Development Economics, 56, 181-206.

Grossman, 2000. "The Human Capital Model." In Handbook of Health Economics, ed. A.J. Culyer and J.P. Newhouse. Amsterdam: Elsevier

Hart, K. 1973. The Informal Income Opportunities and Urban Employment in Ghana. Journal of Modern African Studies. 11. 61-89.

Heckman, J., \& Sedlacek, G. 1985. Heterogeneity, aggregation and market wage functions: An empirical model of self-selection in the labor market. Journal of Political Economy, 93, 1077-1125.

Maloney, William. 2004. "Informality Revisited,"World Development, 32 (7), 1159-78.

Marcoullier, D., Ruiz de Casilla, V., \& Woodruff, C. 1997. Formal measures of the informal-sector wage gap in Mexico, El Salvador, and Peru. Economic Development and Cultural Change, 45(2), 367392.

Lee, L. "Generalized Econometric Models with Selectivity," Econometrica 51 (March 1983): 507-12.

Lundberg, Shelly J., Robert A. Pollak, and Terence J. Wales. 1997. "Do Husbands and Wives Pool Their Resources? Evidence from the United Kingdom Child Benefit" Journal of Human Resources 32 (3): 463-480.

Perry, Guillermo, Omar Arias, Pablo Fajnzylber, William Maloney, Andrew Mason, and Jaime Saavedra, 2007. Informality: Exit and Exclusion, The World Bank, Washington DC.

Portes, A., Blitzner, S., \& Curtis, J. (1986). The urban informal sector in Uruguay: Its internal structure, characteristics, and effects. World Development, 14(6), 727-741.

Pradhan, M., and A. van Soest 1995. Formal and informal sector employment in urban areas of Bolivia. Labour Economics, 2, 275-297.

Pradhan, M., \& van Soest, A. (1997). Household labor supply in urban areas of Bolivia. Review of Economics and Statistics, 79(2), 300-310.

Pyle, D. 1989. Tax Evasion and the Black Economy. New York, NY: St. Martin’s Press.

Saavedra, J., \& Chong, A. (1999). Structural reform, institutions and earnings: Evidence from the formal and informal sectors in urban Peru. Journal of Development Studies, 35(4), :95-116.

Schneider, Fredrich and Dominik Enste, 2000. "Shadow Economies: Size, Causes, and Consequences," Journal of Economic Literature, Vol. 38, 77-114.

Tanzi, Vito. 1999. "Uses and Abuses of Estimates of the Underground Economy, Economic Journal. 109:456 pp. $338-40$ 
Thomas, James. 1999. "Quantifying the Black Economy: 'Measurement without Theory' Yet Again?" Economic Journal, 109:456, pp. 381-89.

Unite Nations and World Bank, 2003. Joint Iraq Needs Assessment: Health.

Wiles, P. 1987. The Second Economy, Its Definitional Problems. In: S. Allesandrini and B. Dallago, Editors, The Unofficial Economy: Consequences and perspectives in different economic systems, Gower Publishing Company. UK.

World Bank. 2005. Social Protection in Transition: Labor Policy, Safety Nets and Pensions. A Policy Note. Middle East and North Africa, Washington DC.

World Bank. 2009. Public Health Expenditure Review for the Period from 2004 to 2007. World Bank. Washington DC. 
Table 1. Worker Characteristics by Employment Status, Coverage of Social Insurance, and Region

\begin{tabular}{|c|c|c|c|c|c|c|c|c|c|c|c|c|}
\hline & \multicolumn{4}{|c|}{ All } & \multicolumn{4}{|c|}{ Urban } & \multicolumn{4}{|c|}{ Rural } \\
\hline & \multicolumn{2}{|c|}{ Formal } & \multicolumn{2}{|c|}{ Informal } & \multicolumn{2}{|c|}{ Formal } & \multicolumn{2}{|c|}{ Informal } & \multicolumn{2}{|c|}{ Formal } & \multicolumn{2}{|c|}{ Informal } \\
\hline & $(\mathrm{H})$ & $(\mathrm{P})$ & $(\mathrm{N})$ & $(\mathrm{S})$ & $(\mathrm{H})$ & $(\mathrm{P})$ & $(\mathrm{N})$ & $(\mathrm{S})$ & $(\mathrm{H})$ & $(\mathrm{P})$ & $(\mathrm{N})$ & $(\mathrm{S})$ \\
\hline \multicolumn{13}{|c|}{ A. Worker Characteristics } \\
\hline Proportion & $7.2 \%$ & $18.0 \%$ & $37.6 \%$ & $37.3 \%$ & $9.3 \%$ & $22.6 \%$ & $36.9 \%$ & $31.2 \%$ & $3.9 \%$ & $11.2 \%$ & $40.2 \%$ & $44.7 \%$ \\
\hline Urban & $56.4 \%$ & $47.2 \%$ & $29.9 \%$ & $20.9 \%$ & $100.0 \%$ & $100.0 \%$ & $100.0 \%$ & $100.0 \%$ & $0.0 \%$ & $0.0 \%$ & $0.0 \%$ & $0.0 \%$ \\
\hline Age & 35.7 & 34.6 & 31.7 & 37.8 & 37.5 & 36.5 & 31.0 & 35.8 & 33.4 & 33.0 & 31.9 & 38.3 \\
\hline Male & $91.1 \%$ & $90.2 \%$ & $95.9 \%$ & $94.4 \%$ & $86.1 \%$ & $81.7 \%$ & $89.6 \%$ & $95.2 \%$ & $97.6 \%$ & $97.8 \%$ & $98.6 \%$ & $94.2 \%$ \\
\hline No schooling & $10.9 \%$ & $8.4 \%$ & $35.0 \%$ & $50.6 \%$ & $9.5 \%$ & $8.0 \%$ & $20.2 \%$ & $33.7 \%$ & $12.7 \%$ & $8.7 \%$ & $41.0 \%$ & $55.2 \%$ \\
\hline $\begin{array}{l}\text { Primary and } \\
\text { below }\end{array}$ & $7.9 \%$ & $7.2 \%$ & $25.1 \%$ & $17.6 \%$ & $5.5 \%$ & $7.0 \%$ & $22.6 \%$ & $22.2 \%$ & $11.0 \%$ & $7.3 \%$ & $26.2 \%$ & $16.3 \%$ \\
\hline Secondary & $25.3 \%$ & $25.1 \%$ & $21.9 \%$ & $17.6 \%$ & $21.4 \%$ & $20.3 \%$ & $25.6 \%$ & $24.9 \%$ & $30.4 \%$ & $29.4 \%$ & $20.4 \%$ & $15.7 \%$ \\
\hline $\begin{array}{l}\text { Tertiary and } \\
\text { above }\end{array}$ & $55.9 \%$ & $59.4 \%$ & $18.0 \%$ & $14.2 \%$ & $63.6 \%$ & $64.8 \%$ & $31.5 \%$ & $19.2 \%$ & $45.9 \%$ & $54.6 \%$ & $12.4 \%$ & $12.8 \%$ \\
\hline $\begin{array}{l}\text { Household } \\
\text { Size }\end{array}$ & 8.2 & 8.6 & 8.6 & 9.7 & 7.8 & 8.2 & 8.2 & 9.8 & 8.7 & 8.9 & 8.8 & 9.6 \\
\hline $\begin{array}{l}\text { Num. of } \\
\text { Children }\end{array}$ & 1.5 & 1.6 & 3.4 & 4.0 & 1.3 & 1.5 & 2.8 & 3.7 & 1.8 & 2.0 & 3.6 & 4.1 \\
\hline Agriculture & $1.0 \%$ & $1.6 \%$ & $27.6 \%$ & $59.3 \%$ & $1.1 \%$ & $1.1 \%$ & $7.7 \%$ & $13.6 \%$ & $0.9 \%$ & $2.0 \%$ & $36.4 \%$ & $71.4 \%$ \\
\hline Num, jobs $>1$ & $17.8 \%$ & $29.7 \%$ & $25.4 \%$ & $12.7 \%$ & $14.0 \%$ & $19.3 \%$ & $10.0 \%$ & $6.3 \%$ & $22.5 \%$ & $38.5 \%$ & $32.4 \%$ & $14.4 \%$ \\
\hline \multicolumn{13}{|c|}{ B. Job Characteristics } \\
\hline $\begin{array}{l}\text { Monthly } \\
\text { earnings } \\
\text { (YR) }\end{array}$ & 35,699 & 25,876 & 31,512 & . & 41,256 & 28,513 & 36,283 & . & 28,521 & 23,523 & 29,490 & . \\
\hline $\begin{array}{l}\text { Hours per } \\
\text { week }\end{array}$ & 42.5 & 39.4 & 49.0 & . & 41.6 & 38.3 & 50.8 & . & 43.7 & 40.4 & 48.2 & . \\
\hline Paild Leave & $97.6 \%$ & $97.8 \%$ & $5.7 \%$ & . & $96.7 \%$ & $96.0 \%$ & $12.6 \%$ & . & $98.8 \%$ & $99.4 \%$ & $2.8 \%$ & . \\
\hline $\begin{array}{l}\text { Health } \\
\text { Insurance }\end{array}$ & $100.0 \%$ & $0.0 \%$ & $1.7 \%$ & & $100.0 \%$ & $0.0 \%$ & $4.2 \%$ & & $100.0 \%$ & $0.0 \%$ & $0.6 \%$ & \\
\hline Public sector & $93.9 \%$ & $98.7 \%$ & $5.2 \%$ & . & $92.1 \%$ & $97.7 \%$ & $10.6 \%$ & . & $96.3 \%$ & $99.5 \%$ & $2.9 \%$ & . \\
\hline $\begin{array}{l}\text { Num. years } \\
\text { of this job }\end{array}$ & 11.1 & 10.4 & 6.3 & . & 12.3 & 11.6 & 5.3 & . & 9.5 & 9.4 & 6.7 & . \\
\hline
\end{tabular}


(Table 1. Continued)

C. Household characteristics

\begin{tabular}{|c|c|c|c|c|c|c|c|c|c|c|c|c|}
\hline $\begin{array}{l}\text { Pensioner } \\
\text { in } \mathrm{HH}\end{array}$ & $10.7 \%$ & $9.7 \%$ & $5.5 \%$ & $4.7 \%$ & $12.1 \%$ & $10.9 \%$ & $7.4 \%$ & $5.6 \%$ & $5.1 \%$ & $6.2 \%$ & $2.6 \%$ & $3.6 \%$ \\
\hline $\begin{array}{l}\text { Enough } \\
\text { Water }\end{array}$ & $50.5 \%$ & $63.2 \%$ & $61.4 \%$ & $63.0 \%$ & $48.3 \%$ & $64.4 \%$ & $60.1 \%$ & $61.0 \%$ & $56.3 \%$ & $59.4 \%$ & $63.5 \%$ & $65.6 \%$ \\
\hline Water & & & & & & & & & & & & \\
\hline $\begin{array}{l}\text { Supply in } \\
\mathrm{HH}\end{array}$ & $68.2 \%$ & $71.2 \%$ & $53.4 \%$ & $53.8 \%$ & $75.7 \%$ & $82.4 \%$ & $73.2 \%$ & $73.9 \%$ & $39.3 \%$ & $36.6 \%$ & $22.7 \%$ & $29.4 \%$ \\
\hline $\begin{array}{l}\text { Water } \\
\text { treated }\end{array}$ & $30.1 \%$ & $24.4 \%$ & $20.0 \%$ & $15.6 \%$ & $36.8 \%$ & $31.2 \%$ & $30.3 \%$ & $26.3 \%$ & $4.4 \%$ & $3.4 \%$ & $4.0 \%$ & $2.7 \%$ \\
\hline $\begin{array}{l}\text { Extra } \\
\text { Household }\end{array}$ & 152,262 & 164,524 & 92,269 & 168,124 & 223,798 & 209,313 & 142,681 & 306,829 & 69,061 & 128,900 & 75,095 & 133,531 \\
\hline $\begin{array}{l}\text { Income } \\
(\mathrm{YR}, \%)\end{array}$ & $62.4 \%$ & $65.1 \%$ & $59.5 \%$ & $65.8 \%$ & $58.1 \%$ & $63.7 \%$ & $59.3 \%$ & $66.6 \%$ & $68.2 \%$ & $66.2 \%$ & $59.6 \%$ & $65.6 \%$ \\
\hline \multicolumn{13}{|c|}{ D. Income Quintile based on nonfood consumption } \\
\hline Quintile1 & $13.4 \%$ & $13.1 \%$ & $31.4 \%$ & $25.4 \%$ & $4.5 \%$ & $6.0 \%$ & $13.3 \%$ & $12.0 \%$ & $24.8 \%$ & $19.3 \%$ & $39.2 \%$ & $28.9 \%$ \\
\hline Quintile2 & $18.3 \%$ & $17.5 \%$ & $21.7 \%$ & $22.4 \%$ & $9.7 \%$ & $11.2 \%$ & $16.0 \%$ & $16.9 \%$ & $29.4 \%$ & $23.0 \%$ & $24.1 \%$ & $23.8 \%$ \\
\hline Quintile3 & $16.1 \%$ & $21.1 \%$ & $16.9 \%$ & $19.8 \%$ & $16.4 \%$ & $17.1 \%$ & $17.7 \%$ & $20.5 \%$ & $15.6 \%$ & $24.8 \%$ & $16.6 \%$ & $19.6 \%$ \\
\hline Quintile4 & $21.7 \%$ & $22.4 \%$ & $14.3 \%$ & $16.9 \%$ & $25.2 \%$ & $24.5 \%$ & $21.1 \%$ & $22.2 \%$ & $17.2 \%$ & $20.7 \%$ & $11.4 \%$ & $15.5 \%$ \\
\hline Quintile5 & $30.6 \%$ & $25.9 \%$ & $15.7 \%$ & $15.6 \%$ & $44.1 \%$ & $41.2 \%$ & $31.9 \%$ & $28.4 \%$ & $13.1 \%$ & $12.2 \%$ & $8.8 \%$ & $12.2 \%$ \\
\hline
\end{tabular}

Notes: H denotes formal wage workers with health insurance as well as pension, P denotes formal wage workers with pension coverage, $\mathrm{N}$ denotes informal wage workers without social insurance, and $\mathrm{S}$ denotes self employed workers without social insurance. 
Table 2. Health, Access to Care, Expenditure by Household Type

\begin{tabular}{|c|c|c|c|c|c|c|c|c|c|c|c|c|c|}
\hline & & \multicolumn{4}{|c|}{ All } & \multicolumn{4}{|c|}{ Urban } & \multicolumn{4}{|c|}{ Rural } \\
\hline & & \multicolumn{2}{|c|}{ Formal } & \multicolumn{2}{|c|}{ Informal } & \multicolumn{2}{|c|}{ Formal } & \multicolumn{2}{|c|}{ Informal } & \multicolumn{2}{|c|}{ Formal } & \multicolumn{2}{|c|}{ Informal } \\
\hline & & $(\mathrm{H})$ & $(\mathrm{P})$ & $(\mathrm{N})$ & (S) & $(\mathrm{H})$ & (P) & $(\mathrm{N})$ & (S) & $(\mathrm{H})$ & $(\mathrm{P})$ & $(\mathrm{N})$ & $(\mathrm{S})$ \\
\hline \multicolumn{14}{|c|}{$\underline{\text { Health }}$} \\
\hline \multirow{2}{*}{$\begin{array}{l}\text { ฮี } \\
\vdots \\
\vdots\end{array}$} & $\begin{array}{l}\text { Chronic } \\
\text { disease }\end{array}$ & $8.0 \%$ & $6.9 \%$ & $8.2 \%$ & $10.0 \%$ & $9.3 \%$ & $8.3 \%$ & $8.9 \%$ & $11.1 \%$ & $2.8 \%$ & $2.9 \%$ & $7.4 \%$ & $8.7 \%$ \\
\hline & Illness & $19.8 \%$ & $17.1 \%$ & $18.8 \%$ & $19.3 \%$ & $21.4 \%$ & $19.3 \%$ & $20.9 \%$ & $21.6 \%$ & $13.2 \%$ & $10.8 \%$ & $16.0 \%$ & $16.5 \%$ \\
\hline \multirow{3}{*}{ 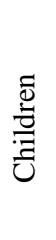 } & $\begin{array}{l}\text { Severe } \\
\text { Stunting }\end{array}$ & $30.1 \%$ & $31.0 \%$ & $35.5 \%$ & $36.4 \%$ & $21.4 \%$ & $19.9 \%$ & $24.8 \%$ & $27.4 \%$ & $38.0 \%$ & $36.6 \%$ & $38.4 \%$ & $38.5 \%$ \\
\hline & $\begin{array}{l}\text { Severe } \\
\text { Under-weight }\end{array}$ & $13.7 \%$ & $9.8 \%$ & $13.8 \%$ & $15.0 \%$ & $9.1 \%$ & $8.4 \%$ & $10.5 \%$ & $13.6 \%$ & $17.9 \%$ & $10.5 \%$ & $14.7 \%$ & $15.3 \%$ \\
\hline & Illness & $19.5 \%$ & $19.8 \%$ & $19.5 \%$ & $17.8 \%$ & $22.9 \%$ & $22.9 \%$ & $22.6 \%$ & $22.9 \%$ & $16.4 \%$ & $18.2 \%$ & $18.6 \%$ & $16.7 \%$ \\
\hline \multicolumn{14}{|c|}{ Access to Service } \\
\hline \multirow{2}{*}{$\begin{array}{l}\tilde{\Phi} \\
\stackrel{0}{0} \\
3\end{array}$} & $\begin{array}{l}\text { Assisted } \\
\text { Delivery }\end{array}$ & $42.3 \%$ & $40.1 \%$ & $30.0 \%$ & $29.6 \%$ & $61.4 \%$ & $58.9 \%$ & $52.4 \%$ & $52.1 \%$ & $20.1 \%$ & $27.7 \%$ & $22.5 \%$ & $24.1 \%$ \\
\hline & $\begin{array}{l}\text { Medical Help } \\
\text { when ill }\end{array}$ & $92.2 \%$ & $87.3 \%$ & $85.0 \%$ & $85.8 \%$ & $95.3 \%$ & $89.9 \%$ & $89.4 \%$ & $89.8 \%$ & $88.1 \%$ & $85.3 \%$ & $83.5 \%$ & $84.8 \%$ \\
\hline 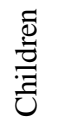 & Immunization & $54.0 \%$ & $51.8 \%$ & $41.0 \%$ & $41.3 \%$ & $60.1 \%$ & $60.7 \%$ & $55.5 \%$ & $56.5 \%$ & $48.6 \%$ & $47.2 \%$ & $36.9 \%$ & $38.0 \%$ \\
\hline \multicolumn{14}{|c|}{ Expenditure } \\
\hline \multirow{3}{*}{ 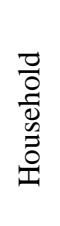 } & $\begin{array}{l}\text { Log(per } \\
\text { capita } \\
\text { spending) }\end{array}$ & 8.3 & 8.0 & 8.0 & 8.1 & 8.6 & 8.3 & 8.4 & 8.2 & 7.7 & 7.9 & 7.8 & 8.0 \\
\hline & Catastropic 1 & $8.8 \%$ & $10.3 \%$ & $12.4 \%$ & $12.1 \%$ & $10.1 \%$ & $8.5 \%$ & $10.0 \%$ & $9.4 \%$ & $7.2 \%$ & $11.6 \%$ & $13.3 \%$ & $12.8 \%$ \\
\hline & Catastropic 2 & $4.9 \%$ & $5.6 \%$ & $7.2 \%$ & $7.3 \%$ & $5.5 \%$ & $4.5 \%$ & $5.8 \%$ & $4.3 \%$ & $4.2 \%$ & $6.4 \%$ & $7.7 \%$ & $8.0 \%$ \\
\hline
\end{tabular}

Notes: Severe stunting and underweight is defined as 1 when the standardized z-score based on Body Mass Index for each measure is below -3 Standard Deviation, and 0 otherwise. 
Table 3. Multinomial Logit Estimates of Employment Type Assignment: Base category is informal wage employment (N)

\begin{tabular}{|c|c|c|c|c|c|c|}
\hline \multirow{3}{*}{ Employment type } & \multicolumn{3}{|c|}{ Urban } & \multicolumn{3}{|c|}{ Rural } \\
\hline & (1) & $(2)$ & (3) & $(4)$ & $(5)$ & (6) \\
\hline & Formal $(\mathrm{H})$ & Formal $(\mathrm{P})$ & Self $(\mathrm{S})$ & Formal $(\mathrm{H})$ & Formal $(\mathrm{P})$ & Self (S) \\
\hline \multirow[t]{2}{*}{ Age } & $0.053 * * *$ & $0.047 * * *$ & $0.027 * * *$ & $0.046^{* * *}$ & $0.048 * * *$ & $0.046 * * *$ \\
\hline & $(0.005)$ & $(0.004)$ & $(0.003)$ & $(0.009)$ & $(0.006)$ & $(0.003)$ \\
\hline \multirow[t]{2}{*}{ Married } & $0.311 * *$ & $0.525 * * *$ & $0.131 *$ & 0.242 & $0.916 * * *$ & $-0.341 * * *$ \\
\hline & $(0.122)$ & $(0.087)$ & $(0.069)$ & $(0.205)$ & $(0.149)$ & $(0.088)$ \\
\hline \multirow[t]{2}{*}{ Less than primary } & $0.916 * * *$ & $0.887 * * *$ & 0.025 & $1.240 * * *$ & $1.366 * * *$ & 0.052 \\
\hline & $(0.193)$ & $(0.132)$ & $(0.085)$ & $(0.314)$ & $(0.222)$ & $(0.091)$ \\
\hline \multirow[t]{2}{*}{ Primary } & $1.636 * * *$ & $1.513 * * *$ & -0.023 & $2.270 * * *$ & $2.601 * * *$ & 0.076 \\
\hline & $(0.156)$ & $(0.114)$ & $(0.078)$ & $(0.264)$ & $(0.191)$ & $(0.090)$ \\
\hline \multirow[t]{2}{*}{ Secondary + } & $2.638 * * *$ & $2.722 * * *$ & $-0.186^{* *}$ & $3.298 * * *$ & $4.030 * * *$ & $0.405 * * *$ \\
\hline & $(0.148)$ & $(0.110)$ & $(0.080)$ & $(0.272)$ & $(0.196)$ & $(0.103)$ \\
\hline \multirow[t]{2}{*}{ Household head } & $0.637 * * *$ & $0.416 * * *$ & 0.075 & 0.115 & -0.040 & $-0.170^{*}$ \\
\hline & $(0.127)$ & $(0.091)$ & $(0.077)$ & $(0.207)$ & $(0.138)$ & $(0.091)$ \\
\hline \multirow[t]{2}{*}{ Household size } & $0.034 * * *$ & $0.033 * * *$ & $0.075^{* * *}$ & -0.014 & -0.003 & $0.036 * * *$ \\
\hline & $(0.010)$ & $(0.007)$ & $(0.006)$ & $(0.018)$ & $(0.011)$ & $(0.007)$ \\
\hline Pensioner & $0.457 * * *$ & $0.317 * * *$ & -0.144 & 0.261 & 0.194 & 0.264 \\
\hline in the $\mathrm{HH}$ & $(0.132)$ & $(0.104)$ & $(0.103)$ & $(0.328)$ & $(0.233)$ & $(0.172)$ \\
\hline \multirow[t]{2}{*}{ Born here } & $0.223 * *$ & $0.234 * * *$ & $0.270 * * *$ & -0.334 & 0.332 & $0.250 * *$ \\
\hline & $(0.087)$ & $(0.064)$ & $(0.053)$ & $(0.273)$ & $(0.209)$ & $(0.117)$ \\
\hline \multirow[t]{2}{*}{ Constant } & $-6.194 * * *$ & $-5.032 * * *$ & $-2.052 * * *$ & $-4.892 * * *$ & $-6.019 * * *$ & $-1.680 * * *$ \\
\hline & $(0.296)$ & $(0.215)$ & $(0.161)$ & $(0.525)$ & $(0.392)$ & $(0.196)$ \\
\hline $\begin{array}{l}\text { Governorate } \\
\text { dummies }\end{array}$ & Yes & Yes & Yes & Yes & Yes & Yes \\
\hline $\mathrm{N}$ & 1,039 & 2,391 & 4,018 & 272 & 775 & 3,313 \\
\hline
\end{tabular}

Note: $* * * \mathrm{p}<0.01, * * \mathrm{p}<0.05, * \mathrm{p}<0.1$. The Pseudo $\mathrm{R}$ squared value for the estimation is 0.25 and 0.17 for urban and rural, respectively. Formal (H) denotes formal wage employed with pension and health insurance, Formal (P) denotes formal employed with pension coverage only, and Self (S) denotes self employment without any social insurance. Omitted category is Informal (N) which denotes wage employment without social insurance coverage. 
Table 4. Selectivity Corrected Estimation of Child's Severe Stunting in Urban Areas

\begin{tabular}{|c|c|c|c|c|c|c|c|c|}
\hline \multirow[t]{2}{*}{ Children $<6$} & \multicolumn{2}{|c|}{$\begin{array}{c}\text { (1) } \\
\text { Formal }(\mathrm{H}) \\
\end{array}$} & \multicolumn{2}{|c|}{$\begin{array}{c}(2) \\
\text { Formal (P) } \\
\end{array}$} & \multicolumn{2}{|c|}{$\begin{array}{c}(3) \\
\text { Informal }(\mathrm{N})\end{array}$} & \multicolumn{2}{|c|}{$\begin{array}{c}\text { (4) } \\
\text { Self (S) } \\
\end{array}$} \\
\hline & Coefficient & S.E. & Coefficient & S.E. & Coefficient & S.E. & Coefficient & S.E. \\
\hline Child's age & $0.037 * * *$ & 0.007 & $0.014 *$ & 0.009 & 0.013 & 0.008 & $0.027 * * *$ & 0.007 \\
\hline Age & -0.003 & 0.002 & $-0.007 * * *$ & 0.002 & -0.001 & 0.001 & $-0.005^{* *}$ & 0.002 \\
\hline Less than primary & $-0.078 * *$ & 0.037 & $-0.119 * * *$ & 0.028 & -0.019 & 0.020 & -0.048 & 0.031 \\
\hline Primary & $-0.122 * * *$ & 0.041 & $-0.096 * * *$ & 0.031 & -0.041 & 0.033 & -0.040 & 0.035 \\
\hline Secondary + & $-0.103 * *$ & 0.054 & $-0.077 * * *$ & 0.035 & $-0.120 * * *$ & 0.026 & -0.035 & 0.066 \\
\hline Number of children $<=5$ & $0.030 * *$ & 0.014 & $0.012 *$ & 0.007 & $0.015^{* *}$ & 0.006 & 0.003 & 0.007 \\
\hline Quintile2 & 0.050 & 0.086 & 0.017 & 0.060 & -0.049 & 0.028 & $-0.079 *$ & 0.044 \\
\hline Quintile3 & 0.075 & 0.082 & 0.059 & 0.047 & -0.015 & 0.029 & $-0.082 *$ & 0.043 \\
\hline Quintile4 & 0.065 & 0.072 & 0.033 & 0.031 & $-0.100 * *$ & 0.039 & $-0.086^{* * *}$ & 0.030 \\
\hline Quintile5 & 0.107 & 0.077 & -0.003 & 0.040 & $-0.108 * * *$ & 0.031 & $-0.095 * * *$ & 0.035 \\
\hline Smoking/ qat chewing & -0.007 & 0.065 & 0.031 & 0.024 & -0.025 & 0.028 & $-0.051 * * *$ & 0.020 \\
\hline Breastfeeding & -0.211 & 0.170 & 0.006 & 0.078 & 0.082 & 0.091 & -0.018 & 0.087 \\
\hline Enough Water & -0.075 & 0.053 & -0.039 & 0.021 & 0.001 & 0.024 & -0.019 & 0.012 \\
\hline Water supply inside house & 0.018 & 0.023 & $-0.044 * *$ & 0.022 & $-0.059 * * *$ & 0.015 & -0.013 & 0.021 \\
\hline Water treated & $-0.118 * * *$ & 0.037 & $-0.087 * * *$ & 0.014 & $-0.068 * * *$ & 0.021 & -0.029 & 0.018 \\
\hline$\lambda_{j}$ & -0.027 & 0.031 & -0.002 & 0.020 & 0.042 & 0.040 & $0.168 * * *$ & 0.041 \\
\hline Constant & 0.218 & 0.152 & $0.485 * * *$ & 0.076 & $0.420 * * *$ & 0.082 & $0.669 * * *$ & 0.104 \\
\hline
\end{tabular}

Note: $* * * \mathrm{p}<0.01, * * \mathrm{p}<0.05, * \mathrm{p}<0.1$. Standard Errors are obtained from bootstrapping. Omitted categories are "no education" and "Quintile 1." The results of selection equation are not presented here. See Table 3 for multinomial logit estimation of selection. 
Table 5. Selectivity Corrected Estimation of Child's Severe Stunting in Rural Areas

\begin{tabular}{|c|c|c|c|c|c|c|c|c|}
\hline \multirow[t]{2}{*}{ Children $<6$} & \multicolumn{2}{|c|}{$\begin{array}{c}(1) \\
\text { Formal }(\mathrm{H}) \\
\end{array}$} & \multicolumn{2}{|c|}{$\begin{array}{c}(2) \\
\text { Formal }(\mathrm{P}) \\
\end{array}$} & \multicolumn{2}{|c|}{$\begin{array}{c}(3) \\
\text { Informal }(\mathrm{N})\end{array}$} & \multicolumn{2}{|c|}{$\begin{array}{c}(4) \\
\text { Self }(\mathrm{S})\end{array}$} \\
\hline & Coefficient & S.E. & Coefficient & S.E. & Coefficient & S.E. & Coefficient & S.E. \\
\hline Child's age & 0.029 & 0.027 & 0.013 & 0.013 & 0.013 & 0.008 & $0.023 * * *$ & 0.010 \\
\hline Age & $-0.010 *$ & 0.005 & $-0.008 * *$ & 0.004 & -0.000 & 0.002 & -0.002 & 0.002 \\
\hline Less than primary & 0.012 & 0.128 & $-0.115^{* *}$ & 0.055 & 0.011 & 0.046 & $-0.069 *$ & 0.043 \\
\hline Primary & $-0.222 * *$ & 0.108 & -0.027 & 0.063 & -0.085 & 0.057 & -0.098 & 0.064 \\
\hline Secondary + & 0.212 & 0.213 & $-0.167 * *$ & 0.084 & -0.013 & 0.150 & -0.019 & 0.102 \\
\hline Number of children $<=5$ & 0.046 & 0.031 & -0.005 & 0.011 & 0.001 & 0.009 & 0.011 & 0.007 \\
\hline Quintile2 & -0.012 & 0.115 & 0.012 & 0.049 & $-0.062 * *$ & 0.027 & 0.038 & 0.030 \\
\hline Quintile3 & -0.090 & 0.112 & -0.002 & 0.056 & -0.050 & 0.037 & 0.007 & 0.033 \\
\hline Quintile4 & 0.143 & 0.140 & -0.052 & 0.056 & -0.037 & 0.043 & 0.036 & 0.038 \\
\hline Quintile5 & -0.046 & 0.156 & -0.052 & 0.075 & -0.034 & 0.050 & -0.015 & 0.047 \\
\hline Smoking/ qat chewing & $0.255^{* *}$ & 0.105 & 0.073 & 0.051 & $0.083 * * *$ & 0.027 & $0.048 *$ & 0.029 \\
\hline Breastfeeding & 0.010 & 0.330 & $-0.324 * * *$ & 0.072 & -0.090 & 0.083 & $-0.251 * * *$ & 0.082 \\
\hline Enough Water & $-0.131 *$ & 0.079 & 0.008 & 0.043 & -0.010 & 0.027 & $-0.055^{* *}$ & 0.026 \\
\hline Water supply inside house & 0.015 & 0.102 & $-0.078 * *$ & 0.034 & -0.023 & 0.032 & -0.017 & 0.026 \\
\hline Water treated & 0.112 & 0.223 & $-0.194 * *$ & 0.090 & $-0.095^{*}$ & 0.056 & $-0.295 * * *$ & 0.071 \\
\hline$\lambda_{j}$ & 0.104 & 0.103 & 0.062 & 0.049 & $-0.138 * * *$ & 0.028 & -0.046 & 0.050 \\
\hline Constant & $0.689 * *$ & 0.301 & $0.706 * * *$ & 0.156 & $0.252 * * *$ & 0.063 & $0.364 * * *$ & 0.088 \\
\hline
\end{tabular}

Note: $* * * \mathrm{p}<0.01, * * \mathrm{p}<0.05, * \mathrm{p}<0.1$. Standard Errors are obtained from bootstrapping. Omitted categories are "no education" and "Quintile 1.” The results of selection equation are not presented here. See Table 3 for multinomial logit estimation of selection. 
Table 6. Selectivity Corrected Estimation of Women's illness in Urban Areas

\begin{tabular}{|c|c|c|c|c|c|c|c|c|}
\hline \multirow[t]{2}{*}{ Married Women } & \multicolumn{2}{|c|}{$\begin{array}{c}(1) \\
\text { Formal }(\mathrm{H}) \\
\end{array}$} & \multicolumn{2}{|c|}{$\begin{array}{c}(2) \\
\text { Formal }(\mathrm{P}) \\
\end{array}$} & \multicolumn{2}{|c|}{$\begin{array}{c}(3) \\
\text { Informal }(\mathrm{N})\end{array}$} & \multicolumn{2}{|c|}{$\begin{array}{c}(4) \\
\text { Self }(S) \\
\end{array}$} \\
\hline & Coefficient & S.E. & Coefficient & S.E. & Coefficient & S.E. & Coefficient & S.E. \\
\hline Age & $0.005 * * *$ & 0.002 & $0.004 * * *$ & 0.001 & $0.007 * * *$ & 0.001 & $0.005 * * *$ & 0.001 \\
\hline Less than primary & 0.083 & 0.056 & -0.013 & 0.027 & 0.031 & 0.019 & -0.028 & 0.027 \\
\hline Primary & -0.011 & 0.049 & -0.034 & 0.028 & -0.012 & 0.020 & 0.003 & 0.025 \\
\hline Secondary + & $-0.092 *$ & 0.051 & -0.041 & 0.035 & -0.041 & 0.027 & $-0.075 * * *$ & 0.024 \\
\hline Number of children $<=5$ & 0.003 & 0.012 & $-0.014 * * *$ & 0.005 & $-0.011 * *$ & 0.004 & $-0.011 * * *$ & 0.004 \\
\hline Quintile2 & 0.085 & 0.053 & -0.019 & 0.047 & 0.013 & 0.031 & 0.012 & 0.029 \\
\hline Quintile3 & -0.037 & 0.052 & 0.044 & 0.042 & 0.044 & 0.030 & $0.067 * *$ & 0.031 \\
\hline Quintile4 & 0.094 & 0.071 & 0.038 & 0.040 & 0.044 & 0.028 & 0.017 & 0.031 \\
\hline Quintile5 & $0.134 * *$ & 0.047 & $0.080 * *$ & 0.034 & $0.092 * * *$ & 0.025 & $0.095 * * *$ & 0.028 \\
\hline Smoking/ qat chewing & $0.077^{*}$ & 0.044 & $0.091 * * *$ & 0.034 & $0.098 * * *$ & 0.024 & $0.072 * * *$ & 0.019 \\
\hline Enough Water & -0.038 & 0.026 & $-0.057 * *$ & 0.024 & $-0.049 *$ & 0.029 & -0.026 & 0.027 \\
\hline Water supply inside house & 0.010 & 0.047 & 0.015 & 0.037 & -0.009 & 0.032 & -0.045 & 0.035 \\
\hline Water treated & -0.017 & 0.020 & 0.010 & 0.014 & 0.004 & 0.012 & -0.041 & 0.014 \\
\hline$\lambda_{j}$ & -0.039 & 0.050 & -0.001 & 0.027 & -0.045 & 0.051 & $0.054 * *$ & 0.027 \\
\hline Constant & -0.084 & 0.135 & 0.082 & 0.070 & -0.058 & 0.048 & 0.005 & 0.001 \\
\hline
\end{tabular}

Note: *** $\mathrm{p}<0.01, * * \mathrm{p}<0.05, * \mathrm{p}<0.1$. Standard Errors are obtained from bootstrapping. Omitted categories are "no education" and "Quintile 1." The results of selection equation are not presented here. See Table 3 for multinomial logit estimation of selection. 
Table 7. Selectivity Corrected Estimation of Women's illness in Rural Areas

\begin{tabular}{|c|c|c|c|c|c|c|c|c|}
\hline \multirow[t]{2}{*}{ Married Women } & \multicolumn{2}{|c|}{$\begin{array}{c}\text { (1) } \\
\text { Formal }(\mathrm{H}) \\
\end{array}$} & \multicolumn{2}{|c|}{$\begin{array}{c}(2) \\
\text { Formal (P) }\end{array}$} & \multicolumn{2}{|c|}{$\begin{array}{c}(3) \\
\text { Informal }(\mathrm{N})\end{array}$} & \multicolumn{2}{|c|}{$\begin{array}{c}(4) \\
\text { Self }(\mathrm{S})\end{array}$} \\
\hline & Coefficient & S.E. & Coefficient & S.E. & Coefficient & S.E. & Coefficient & S.E. \\
\hline Age & 0.005 & 0.004 & -0.002 & 0.002 & $0.005 * * *$ & 0.001 & $0.004 * * *$ & 0.001 \\
\hline Less than primary & -0.043 & 0.063 & -0.019 & 0.049 & 0.000 & 0.027 & 0.032 & 0.034 \\
\hline Primary & 0.042 & 0.115 & $-0.092 * * *$ & 0.032 & -0.003 & 0.047 & -0.044 & 0.038 \\
\hline Secondary + & -0.063 & 0.092 & -0.060 & 0.053 & -0.029 & 0.090 & 0.023 & 0.077 \\
\hline Number of children $<=5$ & 0.012 & 0.020 & $-0.019 * * *$ & 0.007 & -0.008 & 0.007 & -0.004 & 0.005 \\
\hline Quintile2 & 0.007 & 0.074 & -0.022 & 0.038 & -0.020 & 0.019 & -0.003 & 0.021 \\
\hline Quintile3 & 0.038 & 0.091 & -0.010 & 0.032 & 0.007 & 0.025 & 0.003 & 0.021 \\
\hline Quintile4 & 0.027 & 0.079 & 0.022 & 0.048 & 0.007 & 0.025 & 0.028 & 0.024 \\
\hline Quintile5 & -0.047 & 0.105 & 0.072 & 0.048 & 0.049 & 0.033 & 0.038 & 0.023 \\
\hline Smoking/ qat chewing & 0.201 & 0.127 & 0.078 & 0.048 & $0.089 * * *$ & 0.024 & $0.054^{*}$ & 0.030 \\
\hline Enough Water & -0.034 & 0.060 & 0.007 & 0.032 & $0.038 * *$ & 0.015 & -0.019 & 0.026 \\
\hline Water supply inside house & -0.057 & 0.082 & $-0.050 * *$ & 0.021 & $-0.073 * * *$ & 0.021 & $-0.044 * *$ & 0.019 \\
\hline Water treated & -0.023 & 0.117 & -0.005 & 0.060 & -0.002 & 0.043 & -0.036 & 0.049 \\
\hline$\lambda_{j}$ & $0.173 *$ & 0.092 & -0.030 & 0.024 & $-0.100 * *$ & 0.044 & 0.025 & 0.034 \\
\hline Constant & 0.284 & 0.234 & $0.198 * *$ & 0.080 & $-0.083 *$ & 0.043 & 0.036 & 0.062 \\
\hline
\end{tabular}

Note: $* * * \mathrm{p}<0.01, * * \mathrm{p}<0.05, * \mathrm{p}<0.1$. Standard Errors are obtained from bootstrapping. Omitted categories are "no education" and "Quintile 1." The results of selection equation are not presented here. See Table 3 for multinomial logit estimation of selection. 
Table 8. Selectivity Corrected Estimation of Access to Health Service

\begin{tabular}{|c|c|c|c|c|c|c|c|c|}
\hline \multirow[b]{2}{*}{ A. Urban } & \multicolumn{2}{|c|}{$\begin{array}{c}\text { (1) } \\
\text { Formal }(\mathrm{H}) \\
\end{array}$} & \multicolumn{2}{|c|}{$\begin{array}{c}\text { (2) } \\
\text { Formal }(\mathrm{P}) \\
\end{array}$} & \multicolumn{2}{|c|}{$\begin{array}{c}(3) \\
\text { Informal }(\mathrm{N}) \\
\end{array}$} & \multicolumn{2}{|c|}{$\begin{array}{c}(4) \\
\text { Self }(S)\end{array}$} \\
\hline & Coefficient & S.E. & Coefficient & S.E. & Coefficient & S.E. & Coefficient & S.E. \\
\hline Age & 0.002 & 0.002 & -0.001 & 0.001 & 0.001 & 0.001 & 0.000 & 0.000 \\
\hline Less than primary & 0.047 & 0.029 & -0.017 & 0.034 & -0.010 & 0.028 & 0.012 & 0.018 \\
\hline Primary & 0.025 & 0.020 & $0.073 * * *$ & 0.024 & $0.076 * * *$ & 0.018 & $0.080 * * *$ & 0.026 \\
\hline Secondary + & 0.047 & 0.038 & $0.051 * * *$ & 0.019 & $0.063 * * *$ & 0.019 & 0.046 & 0.034 \\
\hline Number of children $<=5$ & 0.002 & 0.008 & $-0.025 * * *$ & 0.005 & $-0.016 * * *$ & 0.005 & $-0.013 * * *$ & 0.003 \\
\hline Quintile2 & -0.005 & 0.034 & 0.002 & 0.043 & -0.002 & 0.035 & -0.024 & 0.029 \\
\hline Quintile3 & 0.003 & 0.032 & 0.040 & 0.056 & 0.005 & 0.033 & -0.011 & 0.028 \\
\hline Quintile4 & -0.025 & 0.044 & $0.081 *$ & 0.047 & 0.017 & 0.033 & -0.030 & 0.027 \\
\hline Quintile5 & -0.014 & 0.033 & $0.092 * *$ & 0.044 & $0.061 * *$ & 0.028 & -0.021 & 0.027 \\
\hline Disabled member in the $\mathrm{HH}$ & 0.025 & 0.022 & $0.052 * * *$ & 0.014 & $0.040 *$ & 0.021 & $0.030 * *$ & 0.012 \\
\hline$\lambda_{j}$ & -0.000 & 0.044 & $-0.078 * * *$ & 0.021 & 0.022 & 0.044 & -0.013 & 0.037 \\
\hline Constant & 0.895 & 0.086 & $0.747 * * *$ & 0.087 & $0.825 * * *$ & 0.061 & $0.849 * * *$ & 0.038 \\
\hline B. Rural & Coefficient & S.E. & Coefficient & S.E. & Coefficient & S.E. & Coefficient & S.E. \\
\hline Age & 0.009 & 0.006 & $-0.006 * * *$ & 0.002 & $-0.002 * *$ & 0.001 & $-0.004 * * *$ & 0.001 \\
\hline Less than primary & $-0.199 * *$ & 0.086 & $-0.198 * * *$ & 0.059 & -0.038 & 0.033 & 0.004 & 0.047 \\
\hline Primary & 0.090 & 0.089 & 0.051 & 0.041 & 0.072 & 0.048 & $0.110 * *$ & 0.054 \\
\hline Secondary + & $0.175^{* *}$ & 0.088 & -0.030 & 0.056 & 0.043 & 0.076 & -0.227 & 0.181 \\
\hline Number of children $<=5$ & -0.020 & 0.026 & $-0.019 *$ & 0.011 & $-0.022 * * *$ & 0.006 & $-0.019 * * *$ & 0.006 \\
\hline Quintile2 & 0.035 & 0.126 & $0.090 *$ & 0.049 & 0.025 & 0.020 & $0.091 * * *$ & 0.025 \\
\hline Quintile3 & -0.047 & 0.130 & $0.111^{* *}$ & 0.043 & 0.024 & 0.031 & $0.093 * *$ & 0.036 \\
\hline Quintile4 & $0.298 * *$ & 0.127 & $0.097 * *$ & 0.043 & -0.006 & 0.032 & $0.085^{* * *}$ & 0.032 \\
\hline Quintile5 & 0.087 & 0.154 & $0.179 * * *$ & 0.041 & 0.024 & 0.031 & $0.082 * *$ & 0.036 \\
\hline Disabled member in the $\mathrm{HH}$ & 0.117 & 0.110 & 0.037 & 0.036 & 0.018 & 0.022 & $0.048 * *$ & 0.024 \\
\hline$\lambda_{j}$ & $0.456^{* * *}$ & 0.123 & -0.047 & 0.041 & $-0.098 * * *$ & 0.044 & $0.204 * * *$ & 0.054 \\
\hline Constant & $1.283 * * *$ & 0.340 & $0.928 * * *$ & 0.092 & 0.808 & 0.051 & $1.081 * * *$ & 0.092 \\
\hline
\end{tabular}

Note: $* * * \mathrm{p}<0.01, * * \mathrm{p}<0.05, * \mathrm{p}<0.1$. Standard Errors are obtained from bootstrapping. Omitted categories are "no education" and "Quintile 1." The results of selection equation are not presented here. 
Table 9. Selectivity Corrected Estimation of Log (Proportion of Health Expenditure)

\begin{tabular}{|c|c|c|c|c|c|c|c|c|}
\hline \multirow[b]{2}{*}{ A. Urban } & \multicolumn{2}{|c|}{$\begin{array}{c}(1) \\
\text { Formal }(\mathrm{H}) \\
\end{array}$} & \multicolumn{2}{|c|}{$\begin{array}{c}(2) \\
\text { Formal }(\mathrm{P}) \\
\end{array}$} & \multicolumn{2}{|c|}{$\begin{array}{c}(3) \\
\text { Informal }(\mathrm{N}) \\
\end{array}$} & \multicolumn{2}{|c|}{$\begin{array}{c}(4) \\
\text { Self }(\mathrm{S}) \\
\end{array}$} \\
\hline & Coefficient & S.E. & Coefficient & S.E. & Coefficient & S.E. & Coefficient & S.E. \\
\hline Age & 0.045 & 0.095 & 0.044 & 0.042 & -0.000 & 0.020 & 0.013 & 0.018 \\
\hline Age Squared & -0.001 & 0.001 & -0.000 & 0.001 & -0.000 & 0.000 & -0.000 & 0.000 \\
\hline Less than primary & -0.399 & 0.771 & -0.266 & 0.642 & -0.220 & 0.152 & -0.057 & 0.184 \\
\hline Primary & -0.564 & 0.539 & 0.483 & 0.590 & $-0.350 * *$ & 0.143 & -0.204 & 0.158 \\
\hline Secondary + & $-1.028 * *$ & 0.492 & 0.391 & 0.671 & $-0.433 * *$ & 0.196 & -0.326 & 0.214 \\
\hline Smoking/ qat chewing & -0.205 & 0.227 & $-0.401 * *$ & 0.171 & 0.148 & 0.101 & 0.134 & 0.132 \\
\hline Quintile2 & -0.298 & 0.535 & -0.119 & 0.495 & -0.169 & 0.145 & $-0.425 * *$ & 0.171 \\
\hline Quintile3 & -0.116 & 0.432 & -0.049 & 0.485 & $-0.348 * *$ & 0.136 & $-0.541 * * *$ & 0.161 \\
\hline Quintile4 & -0.160 & 0.426 & 0.124 & 0.496 & $-0.277 * *$ & 0.121 & $-0.493 * * *$ & 0.152 \\
\hline Quintile5 & -0.586 & 0.403 & -0.058 & 0.515 & $-0.412 * * *$ & 0.140 & $-0.669 * * *$ & 0.176 \\
\hline Disabled member in the $\mathrm{HH}$ & 0.098 & 0.188 & $0.296^{*}$ & 0.176 & $0.311 * * *$ & 0.094 & $0.247 * * *$ & 0.093 \\
\hline$\lambda_{j}$ & $1.250 * *$ & 0.610 & -0.521 & 0.462 & 0.004 & 0.263 & -0.030 & 0.171 \\
\hline Constant & -0.010 & 1.997 & $-4.424 * * *$ & 1.430 & $-1.810 * * *$ & 0.407 & $-2.290 * * *$ & 0.366 \\
\hline B. Rural & Coefficient & S.E. & Coefficient & S.E. & Coefficient & S.E. & Coefficient & S.E. \\
\hline Age & -0.013 & 0.191 & -0.099 & 0.074 & -0.011 & 0.021 & 0.004 & 0.013 \\
\hline Age Squared & 0.001 & 0.003 & 0.001 & 0.001 & -0.000 & 0.000 & -0.000 & 0.000 \\
\hline Less than primary & 1.368 & 0.805 & -0.520 & 0.523 & -0.193 & 0.125 & -0.023 & 0.149 \\
\hline Primary & 0.895 & 0.864 & -0.372 & 0.613 & $-0.289 * *$ & 0.143 & -0.067 & 0.178 \\
\hline Secondary + & 1.145 & 0.975 & -0.172 & 0.764 & $-0.418 * *$ & 0.223 & -0.286 & 0.174 \\
\hline Smoking/ qat chewing & -0.121 & 0.856 & 0.185 & 0.287 & $-0.276 * * *$ & 0.099 & -0.060 & 0.123 \\
\hline Quintile2 & 0.038 & 0.615 & -0.313 & 0.432 & $-0.353 * * *$ & 0.110 & $-0.348 * * *$ & 0.121 \\
\hline Quintile3 & 0.153 & 0.630 & -0.524 & 0.405 & $-0.544 * * *$ & 0.122 & $-0.391 * * *$ & 0.126 \\
\hline Quintile4 & -1.302 & 0.681 & -0.003 & 0.462 & $-0.423 * * *$ & 0.142 & $-0.301 * *$ & 0.139 \\
\hline Quintile5 & -0.846 & 0.722 & -0.280 & 0.484 & $-0.504 * * *$ & 0.158 & $-0.638 * * *$ & 0.219 \\
\hline Disabled member in the $\mathrm{HH}$ & 0.771 & 0.656 & 0.227 & 0.227 & $0.149^{*}$ & 0.089 & $0.311 * * *$ & 0.098 \\
\hline$\lambda_{j}$ & 0.469 & 0.934 & -0.283 & 0.452 & -0.238 & 0.220 & -0.290 & 0.257 \\
\hline Constant & -2.985 & 4.204 & -0.561 & 1.915 & $-1.301 * * *$ & 0.387 & $-2.392 * * *$ & 0.316 \\
\hline
\end{tabular}

Note: $* * * \mathrm{p}<0.01, * * \mathrm{p}<0.05, * \mathrm{p}<0.1$. Standard Errors are obtained from bootstrapping. Omitted categories are "no education" and "Quintile 1." The results of selection equation are not presented here. 
Table 10. Decomposition of differences in outcomes

\begin{tabular}{|c|c|c|c|c|c|c|c|c|}
\hline & \multicolumn{4}{|c|}{ Urban Areas } & \multicolumn{4}{|c|}{ Rural Areas } \\
\hline & $\bar{O}_{l}^{(1)}-\bar{O}_{J}$ & $\left(\widehat{\beta}_{\mathrm{i}}-\widehat{\beta}_{\mathrm{j}}\right)^{\prime} \overline{\mathrm{Z}}_{\mathrm{l}}$ & $\hat{\beta}_{\mathrm{j}}{ }^{\prime}\left(\overline{\mathrm{Z}}_{1}-\overline{\mathrm{Z}}_{\mathrm{j}}\right)$ & $\left(\hat{\gamma}_{\mathrm{i}} \bar{\lambda}_{\mathrm{l}}^{(4)}-\hat{\gamma}_{\mathrm{j}} \bar{\lambda}_{\mathrm{j}}\right)$ & $\bar{O}_{l}^{(5)}-\bar{O}_{J}$ & $\left(\widehat{\beta}_{\mathrm{i}}-\widehat{\beta}_{\mathrm{j}}\right)^{\prime} \overline{\mathrm{Z}}_{\mathrm{l}}$ & $\left.\hat{\beta}_{\mathrm{j}}{ }^{\prime\left(\overline{\mathrm{Z}_{1}}\right.}-\overline{\overline{\mathrm{Z}}_{\mathrm{j}}}\right)$ & $\left(\hat{\gamma}_{i} \bar{\lambda}_{1}^{(8)}-\hat{\gamma}_{j} \bar{\lambda}_{j}\right)$ \\
\hline \multicolumn{9}{|c|}{ Child: Severe Stunting } \\
\hline $\mathrm{H}-\mathrm{N}$ & $-0.022 * * *$ & -0.060 & -0.043 & 0.081 & $0.011 *$ & 0.337 & -0.029 & -0.296 \\
\hline $\mathrm{P}-\mathrm{N}$ & $-0.035 * * *$ & -0.048 & -0.032 & 0.045 & $-0.044 * * *$ & 0.164 & -0.021 & -0.187 \\
\hline S-N & $0.034 * * *$ & 0.153 & 0.009 & -0.128 & -0.002 & 0.078 & -0.003 & -0.077 \\
\hline \multicolumn{9}{|c|}{ Women: Illness } \\
\hline $\mathrm{H}-\mathrm{N}$ & 0.003 & -0.034 & 0.027 & 0.010 & $-0.034 * * *$ & 0.394 & -0.034 & -0.394 \\
\hline $\mathrm{P}-\mathrm{N}$ & $-0.014 * * *$ & 0.020 & 0.011 & -0.046 & $-0.051 * * *$ & 0.032 & -0.032 & -0.051 \\
\hline S-N & $0.006^{* *}$ & 0.076 & 0.028 & -0.098 & $0.006^{* *}$ & 0.086 & 0.026 & -0.106 \\
\hline \multicolumn{9}{|c|}{ Access: Medical help when sick } \\
\hline $\mathrm{H}-\mathrm{N}$ & $0.137 * * *$ & 0.089 & 0.025 & 0.023 & -0.019 & 0.869 & 0.006 & -0.894 \\
\hline $\mathrm{P}-\mathrm{N}$ & 0.000 & -0.123 & 0.016 & 0.107 & 0.025 & 0.054 & 0.001 & -0.029 \\
\hline $\mathrm{S}-\mathrm{N}$ & 0.004 & -0.025 & -0.007 & 0.035 & 0.007 & 0.264 & -0.014 & -0.244 \\
\hline \multicolumn{9}{|c|}{ Expenditure: Proportion of health expenditure } \\
\hline $\mathrm{H}-\mathrm{N}$ & 0.005 & 1.622 & -0.211 & -1.406 & $0.255^{* * *}$ & -1.939 & -0.216 & 2.410 \\
\hline $\mathrm{P}-\mathrm{N}$ & $-0.169 * * *$ & -0.345 & -0.189 & 0.365 & $-0.053 * *$ & -0.312 & -0.298 & 0.556 \\
\hline $\mathrm{S}-\mathrm{N}$ & $-0.037 * * *$ & 0.502 & -0.040 & -0.499 & -0.015 & 0.461 & -0.203 & -0.273 \\
\hline
\end{tabular}

Note: $* * *, * *$, and $*$ in columns (1) and (5) denote statistical significance at $1 \%, 5 \%$, and $10 \%$ level, respectively, from the test of the null hypothesis $H_{o}: \overline{O_{i}}-\overline{O_{j}}=0$ 
Table 11. Informal Safety Net: The Impacts of Disabled Household Member

\begin{tabular}{|c|c|c|c|c|c|c|c|c|}
\hline \multirow[t]{2}{*}{ Dependent variables } & \multicolumn{2}{|c|}{$\begin{array}{c}(1) \\
\text { Formal }(\mathrm{H}) \\
\end{array}$} & \multicolumn{2}{|c|}{$\begin{array}{c}(2) \\
\text { Formal(P) }\end{array}$} & \multicolumn{2}{|c|}{$\begin{array}{c}(3) \\
\text { Informal }(\mathrm{N})\end{array}$} & \multicolumn{2}{|c|}{$\begin{array}{c}(4) \\
\text { Self (S) }\end{array}$} \\
\hline & Coefficient & S.E. & Coefficient & S.E. & Coefficient & S.E. & Coefficient & S.E. \\
\hline Transfer income & 0.037 & 0.065 & 0.031 & 0.033 & $0.060 * *$ & 0.032 & $0.040 * *$ & 0.020 \\
\hline Borrowing & $0.067 * * *$ & 0.023 & $0.093 * * *$ & 0.033 & $0.064 * *$ & 0.032 & $0.128 * * *$ & 0.039 \\
\hline B. Rural & Coefficient & S.E. & Coefficient & S.E. & Coefficient & S.E. & Coefficient & S.E. \\
\hline Transfer income & -0.085 & 0.104 & $0.227 * * *$ & 0.031 & $0.059 * * *$ & 0.021 & $0.060 * *$ & 0.026 \\
\hline Borrowing & 0.018 & 0.085 & $0.092 * * *$ & 0.030 & $0.116^{* * *}$ & 0.045 & $0.113 * * *$ & 0.029 \\
\hline
\end{tabular}

Notes: The coefficients of an indicator of disabled household member are obtained from two separate regressions on transfer income and borrowing separately for each region. 